\title{
Financial Literature And Interest Of Aceh People In Transactions In Sharia Financial Institutions Post Implementation Of Qanun Sharia Financial Institutions In Aceh
}

\author{
Mai Simahatie ${ }^{1 *}$, Marliyah $^{2}$ Zulkifli Yusuf $^{3}$ \\ ${ }^{1,2}$ Fakultas Ekonomi dan Bisnis Islam Universitas Islam Negeri Sumatera Utara ${ }^{3}$ Fakultas Ekonomi dan \\ Bisnis Universitas Malikussaleh
}

*Email Corespondent : maisimahatie@gmail.com

\begin{abstract}
Financial literacy is a very important element of knowledge for the economic progress of a country because it is closely related to public interest, the higher the level of public financial literacy, the easier it is for the financial system to be accepted in the community to be implemented and contribute to the economic growth of a region, because with The high level of financial literacy in the community, the easier it will be for financial institutions to provide financial access to the public. the enactment of qanun no 11 of 2018 regarding Islamic financial institutions in Aceh has begun since January 4, 2019, all financial institutions in Aceh. In this study, the data used is secondary data obtained from scientific references as quoted from journals, books texts, working papers, national and international scientific forums and other sources deemed relevant to this research. the results of the research and discussion, it can be concluded that nationally the financial literacy of the Indonesian people is still relatively low, but for the Aceh region itself it is higher than the level of public understanding of sharia finance in Aceh which is above the average public understanding of sharia banking nationally. The interest of the Acehnese people in transacting in Islamic banking is currently increasing, as can be seen from the increasing graph in terms of assets, financing, and third party funds, especially in 2021.
\end{abstract}

Keywords : Financial Literacy, Interests, Islamic financial institutions

\begin{abstract}
Abstrak: Literasi keuangan merupakan elemen pengetahuan yang sangat penting bagi kemajuan ekonomi suatu negara karena erat karitan nya dengan minat masyarakat, semakin tinggi tingkat literasi keuangan masyarakat maka semakin mudah sistem keuangan diterima di tengah tengah masyarakat untuk diimplementasikan dan memberikan kontribusi bagi pertumbuhan ekonomi suatu daerah, dikarenakan dengan tingginya tingkat literasi keuangan di masyarakat, maka akan semakin mudah lembagalembaga keuangan memberikan akses keuangan kepada masyarakat. pemberlakuan qanun no 11 tahun 2018 perihal lembaga keuangan syariah di Aceh telah dimulai sejak tanggal 04 Januari 2019, semua lembaga keuangan yang ada di Aceh.Dalam penelitian ini, data yang digunakan merupakan data skunder yang didapatkan dari berupa referensi ilmiah seperti dikutip dari jurnal, buku teks, kertas kerja, forum ilmiah nasional dan internasiol dan sumber sumber lain yang dianggap relevan dengan penelitian ini. hasil
\end{abstract}




\begin{abstract}
penelitian dan pembahasan maka dapat disimpulkan bahwa secara nasional literasi keuangan masyarakat Indonesia masih tergolong rendah, namun untuk wilayah Aceh sendiri berada lebih tinggi dari Tingkat pemahaman masyarakat terhadap keuangan syariah di Aceh berada di atas rata-rata pemahaman masyarakat terhadap perbankan syariah secara nasional. Minat masyarakat Aceh dalam bertransaksi di perbankan syariah saat ini meningkat terlihat dari grafik yang meningkat baik dari segi Aset, pembiayaan, dan dana pihak ketiga terutama di tahun 2021
\end{abstract}

\title{
Keywords : Literasi Keuangan, Minat, lembaga keuangan syariah
}

\section{INTRODUCTION}

This Qanun has been in effect since January 4, 2019 where Financial Institutions operating in Naggroe Aceh Darussalam are required to comply with the Qanun no later than 3 (three) years since the enactment of this Qanun Law. Sharia Financial Institutions are Sharia Banks, Non-Bank Financial Institutions and Other Financial Institutions.

Ironically, even though in Aceh all financial institutions are sharia-based financial institutions, in fact the financial literacy of the Acehnese people regarding Islamic financial institutions is still very lacking, and the lack of Islamic financial literacy that they have will certainly affect the customer's lack of interest in conducting transactions in Indonesia. Islamic financial institutions in Aceh, not only in Aceh, nationally financial literacy is also seen to be still very low.

Based on the agency's data, the index did not reach 10 percent or only 8.93 percent. "While the national literacy index is 38.03 percent.

This condition is also followed by Islamic financial inclusion which is still relatively weak. OJK noted that sharia financial inclusion until 2020 was only around 9.1 percent or far behind the national inclusion which had touched 76.10 percent. Meanwhile, the market share of Islamic finance was low with a proportion of total assets of 9.9 percent.

For the Aceh region, financial literacy in 2019 was $38.03 \%$, this shows that the Acehnese people who understand financial literacy are still very low. Not yet reached half of the population in Aceh Province.

Financial literacy itself is a very important element of knowledge for the economic progress of a country because it is closely related to public interest, the higher the level of public financial literacy, the easier it is for the financial system to be accepted in the community to be implemented and contribute to the economic growth of a region. Due to the high level of financial literacy in the community, it will be easier for financial institutions to provide financial access to the community.

The good financial literacy that the community has regarding Islamic financial institutions will affect the public's interest in conducting transactions in a financial institution, but as stated above, the financial literacy of the Acehnese people is still very low, not reaching $50 \%$ of the total population of Aceh Province. .
In fact, as we know, the implementation of qanun no 11 of 2018 regarding Islamic financial institutions in Aceh has begun since January 4, 2019, all financial institutions in Aceh such as banks have migrated loans, deposits and all their products to Islamic banks, not only its products but also all its employees have migrated from conventional banks to Islamic banks, such as BRI Syariah Bank, BNI Syariah, and Mandiri Syariah.

In addition, starting from February 1, 2021, there has been a merger of three Islamic banks, namely BRISyariah, BNISyariah and Mandiri Syariah to become Bank Syariah Indonesia (BSI), so that the banks in Aceh as a whole are Islamic banks, but as the author has said, it is very It is unfortunate if it turns out that the Acehnese, who are almost $100 \%$ Muslim, do not reach half of the population who understand or have financial literacy, especially sharia financial literacy.

Based on the author's own experience who has been in the banking world for twelve (12) years, and participated in the migration process from Conventional BRI Bank to BRISyariah Bank, then also participated in the merger of BRI Syariah Bank, BNI Syariah and Mandiri Syariah to become Bank Indonesian Sharia (BSI) almost all customers do not understand what a sharia bank is and consider the move from conventional banks to Islamic banks only because there are no other bank choices in Aceh and only follow government policies, without knowing what and why they should be migrated.

Based on the description above, the authors are interested in conducting research on the above problems by taking the title Research on Financial Literacy and Acehnese Community Interest in Transactions in Islamic Financial Institutions After the Implementation of Qanun on Islamic Financial Institutions in Aceh.

\section{LITERATURE REVIEW \\ Financial Literacy}

The definition of financial literacy according to OJK is knowledge, skills and beliefs that influence attitudes and behavior to improve the quality of decision making and financial management in order to achieve prosperity

The definition of financial literacy can be explained in many aspects. According to the U.S. Commission on Financial Literacy and Education. (FLEC), financial literacy is the ability to use 
knowledge and skills to manage financial resources effectively to achieve prosperity. The strategy to achieve this is by increasing awareness and access to effective financial education, determining and integrating core financial competencies, improving financial education infrastructure, and identifying, improving, and sharing effective practices. Meanwhile, according to The Association of Chartered Certified Accountants (2014), the term financial literacy includes knowledge of financial concepts, the ability to understand communication about financial concepts, skills to manage personal/company finances, and the ability to make financial decisions in certain situations.

According to the Financial Services Authority, the factors that affect the level of financial literacy are:

1. Gender

2. Education level

3. Income level (Financial Services Authority, 2014).

Chen and Volpe (1998; Mendari and Kewal, 2014) state that financial literacy is divided into 4 (four) aspects, namely:

1. General Personal Finance Knowledge, includes understanding several things related to basic knowledge of personal finance.

2. Saving and borrowing, this section includes knowledge related to savings and loans such as the use of credit cards.

3. Insurance, this section covers basic knowledge of insurance and insurance products such as life insurance and motor vehicle insurance.

4. Investment, this section includes knowledge of market interest rates, mutual funds and investment risks.

Furthermore, there are various levels of financial literacy to assess how well a person has financial literacy. The following are 4 levels of financial literacy based on those issued by the OJK.

1. Well Literate

If there is someone who is at this level, it means that that person has knowledge and also has confidence in financial service institutions. In addition, the person is also familiar with the financial products and services in it.

So, that person really understands the features, benefits, risks, rights and obligations related to financial products and services. They also have a good ability to utilize financial products and services.

2. Sufficient Literate

At this level, a person has knowledge and beliefs regarding financial service institutions and products of financial services. In addition, the person is also familiar with the features, benefits, risks, rights and obligations related to financial products and services.

\section{Less Literate}

Those at this level have knowledge of financial service institutions and financial products and services, nothing more.

4. Not Literate

Those belonging to this level are considered not to have good knowledge and confidence in financial service institutions and financial products and services.

\section{Qanun on Islamic Financial Institutions in Aceh}

Aceh Qanun No. 11 of 2018 concerning Islamic Financial Institutions is a statutory regulation that regulates the activities of Financial Institutions in the context of realizing a just and prosperous Acehnese economy under the auspices of Islamic law. This Qanun is a follow-up to Aceh Qanun no. 8 of 2014 concerning the principles of Islamic Shari'a which explicitly requires that financial institutions operating in Aceh must be carried out based on Shari'ah principles.

This Qanun takes effect on January 4, 2019 where Financial Institutions operating in Aceh are required to comply with this Qanun no later than 3 (three) years from the promulgation of this Qanun. following:

The enforcement of this Qanun applies to the

1. Every Muslim who resides in Aceh or a Legal Entity conducting financial transactions in Aceh

2. Everyone who is Muslim conducts transactions in Aceh

3. Every person who is non-Muslim, Business Entity and/or Legal Entity conducting financial transactions with the Aceh and Regency/City Governments

4. LKS running a business in aceh

5. LKS outside Aceh headquartered in Aceh The financial institutions referred to in this qanun are:

1. Islamic Banks

2. Non-Bank Financial Institutions

3. Other financial institutions

Sharia Financial Institutions, hereinafter abbreviated as LKS, are institutions that carry out activities in the banking sector, non-banking sharia financial sector and other financial sectors in accordance with sharia principles. Sharia Banks are banks that run their business based on sharia principles and by type consist of Sharia Commercial Banks and Sharia People's Financing Banks as well as sharia business units. Meanwhile, Sharia Non-Bank Financial Institutions are institutions engaged in capital market activities, insurance, pension funds, venture capital, pawnshops, cooperatives, financing institutions, factoring, microfinance institutions and other financial services institutions whose implementation does not conflict with the principles of sharia principles. and what is meant by Other Financial Institutions are institutions that do not yet have formal legality. 
In the general Indonesian dictionary, interest is defined as a liking (tendency of the heart) to a concern or desire. Interest is a mental device consisting of a mixture of feelings, expectations, prejudices or other tendencies that lead the individual to a certain choice (Mappiare, 1997).

Interest

Interest is a liking (inclination of the heart) to something. In simple terms, interest can be interpreted as a tendency to pay attention to people and act on people, activities or situations that are the object of that interest accompanied by feelings of pleasure. (Shaleh and Wahab, 2004). Interest is a person's tendency to keep paying attention and remembering some activities. Activities that a person is interested in and pay attention to continuously accompanied by a sense of pleasure (Slameto, 1995).

Interest as a psychological aspect does not only color a person's behavior to carry out activities that cause someone to feel attracted to something. While customers are consumers as providers of funds in the process of transactions for goods or services. Thus the understanding of customer interest according to Schifman and Kanuk (2008) namely external influences, awareness of needs, product introduction and evaluation of alternatives are things that can lead to consumer buying interest. These external influences consist of marketing efforts and socio-cultural factors.

According to the Theory of Reasoned Action (Theory of Reasoned Action) from Fishbein and Ajzen (1975), namely: Human behavior is influenced by the will or intention or interest. Interest is an individual's desire to perform a certain behavior before the behavior is carried out. The existence of an intention/interest to take an action will determine whether the activity will eventually be carried out.

Interest is the motivation that drives people to do what they want when they are free to choose. Every interest will satisfy a need. In carrying out its function, the will is closely related to thoughts and feelings. Thoughts have a tendency to move in the rational sector of analysis, while subtle or sharp feelings crave needs. While the mind functions as a reminder of those thoughts and feelings in harmonious coordination, so that the will can be regulated as well as possible (Sukanto, 1985).

There are several stages of interest, namely:

a. Clear information before choosing

b. Careful consideration before choosing c.

c. Decision to choose

Thus, it can be said that interest is a strong impetus for someone to do everything in realizing the achievement of the goals and ideals that he wants. A great interest in something is a big capital to generate enthusiasm to take the desired action, in this case the customer's interest in sharia banking

\section{Factors Affecting the Awakening of Interest}

Crow and Crow 2001 in (Ro'uf, 2011) argue that there are three factors that influence the emergence of interest, namely:

a. The push factor from within

This means that it leads to needs that arise from within the individual, which are factors related to physical drives, motives, defending oneself from hunger, fear, pain, as well as curiosity to arouse interest in conducting research and so on.

b. Social motive factor

This means that it leads to adjustment to the environment so that it can be accepted and recognized by the environment or activities to meet social needs, such as work, gain status, get attention and appreciation.

c. Emotional or feeling factors

This means that interest is closely related to feelings or emotions, success in activities that are driven by interest will bring a sense of pleasure and strengthen existing interests, otherwise failure will reduce the individual's interest.

Thus, it can be said that interest can arise due to internal factors, social motive factors, and emotional or feeling factors.

Interest in becoming a customer in this case is assumed to be buying interest. Purchase intention (willingness to buy) is part of the behavioral component in the attitude of consuming. According to Kinnear and Taylor (1995) in Dwityanti (2008), buying interest is the stage of the respondent's tendency to act before the buying decision is actually implemented.

A product can be said to have been consumed by consumers if the product has been decided to be purchased. The decision to buy is influenced by the value of the product being evaluated. If the perceived benefit is greater than the sacrifice to get it, then the urge to buy it is higher. On the other hand, if the benefits are smaller than the sacrifices, the buyer will usually refuse to buy and generally switch to evaluating other similar products. In most people, consumer buying behavior is often initiated and influenced by many external stimuli, both in the form of marketing stimuli and stimuli from the environment. These stimuli are then processed within themselves according to their personal characteristics, before finally making a purchase decision. The personal characteristics of consumers used to process these stimuli are very complex and one of them is the motivation to buy.

According to Keller 2002 (in Dwityanti 2008), consumer buying interest is how likely consumers are to switch from one brand to another. Meanwhile, Mittal 1998 (in Dwityanti 2008) found that the function of consumer interest is product quality and service quality. Consumer interest in buying a product is related to the characteristics of a country and its people (Johnsson and Nebenzahl: 1987; Han: 1989; Pisharodi and 
Parameswaran: 1992; Roth and Romeo: 1992 and Nooh and Powers: 1995) in Dwityanti (2008). Furthermore, Oliver (1993) in Dwityanti (2008) states that the purchase experience remains interested in the product, which ultimately leads to repeat purchases.

Thus, from some of the definitions above, it can be concluded that buying interest is an individual's tendency to act before the buying decision is actually implemented.

Interest in becoming a customer in this study is defined as an individual's tendency to act before the decision to become a customer in Islamic banking is actually implemented. Indicators of interest in becoming a customer include interest, desire and belief. Interest is shown by the concentration of attention and feelings of pleasure. Desire is indicated by the urge to want to have. And confidence is indicated by the feeling of individual confidence in the quality, usability and benefits of the product to be purchased.

\section{RESEARCH METHODS}

In this study, the data used is secondary data obtained from scientific references as quoted from journals, textbooks, working papers, national and international scientific forums and other sources deemed relevant to this research.

In analyzing research data, the author uses a descriptive qualitative approach in the form of exploratory literature

\section{RESULT AND DISCUSSION \\ Aceh Financial Literacy}

Currently, the Financial Services Industry in the Aceh Region consists of nine commercial banks, seven Islamic commercial banks, six sharia business units, five BPRs and ten BPRS.

In addition, there are 86 IKNB namely 30 leasing, 46 insurance, one pawnshop, two BPJS, two LKMS, one pension fund, one PMV, two guarantees, one PNM and 20 capital markets consisting of seven securities, one asset manager and 12 galleries. investment.

There are three major impacts that Aceh has contributed to the economy and finance nationally with the implementation of the Qanun LKS in Aceh. explained that there are three impacts for the economy and sharia finance nationally, namely the increase in sharia market share along with the conversion of conventional banks to sharia. Then the increasing public awareness of Islamic finance and the availability of sharia service options for programs launched nationally by the government. specifically for banking, Islamic banking assets in Aceh as of April 30, 2021 reached Rp 51.37 trillion or 82.89 percent of total banking assets in the westernmost province of Indonesia and the increase in sharia market share in line with the implementation of the LKS Qanun. Sharia banks are the distributors of social assistance from ministries and institutions and optimizing the use of sharia banks as distributors of ASN salaries in Aceh Province. Furthermore, for the Sharia Non-Bank Financial Industry (IKNB) in the near future, there will be a pilot project for sharia services, Jamsostek Employment and Agricultural Insurance, as well as encouraging regional sukuk as an alternative capital market instrument for sharia-based regional development financing.

\section{Interest in Transactions at Islamic Financial Institutions}

The interest of the Acehnese people in transactions appears to be increasing, along with an understanding of Islamic banking, despite the fact that there is no Conventional Bank in the Province of Nanggroe Aceh Darussalam, as can be seen from the data published by the Financial Services Authority (OJK) on Assets, Financing and Third Party Funds, which the authors have summarized in the following table:

Total Aset , Pembiayaan, dan Dana Pihak ketiga Bank Pembiayaan Rakyat Syariah

\begin{tabular}{|c|r|r|r|l|}
\hline \multicolumn{1}{|c|}{ Propinsi / Province } & $\begin{array}{c}\text { Aset } \\
\text { (Assets) }\end{array}$ & $\begin{array}{c}\text { Pembiayaan } \\
\text { (Financing) }\end{array}$ & $\begin{array}{c}\text { Dana Pihak Ketiga } \\
\text { (Depositor Funds) }\end{array}$ & \multicolumn{1}{|c|}{$\begin{array}{c}\text { Tahun } \\
\text { (year) }\end{array}$} \\
\hline & & & & \\
\hline Nanggroe Aceh Darussalam & 469331 & 326904 & 301806 & April 2021 \\
\hline Nanggroe Aceh Darussalam & 464927 & 311730 & 298211 & Maret 2021 \\
\hline Nanggroe Aceh Darussalam & 341471 & 229200 & 191531 & Februari 2021 \\
\hline Nanggroe Aceh Darussalam & 327505 & 220218 & 184361 & Januari 2021 \\
\hline Nanggroe Aceh Darussalam & 435,788 & 294,291 & 279,963 & Desember 2020 \\
\hline Nanggroe Aceh Darussalam & 344,561 & 229,759 & 230,120 & Desember 2019 \\
\hline Nanggroe Aceh Darussalam & 298,625 & 195,350 & 210,641 & Desember 2018 \\
\hline
\end{tabular}

sumber : 0jk.go.id

seen an increase in terms of assets, financing, and third party funds, especially in 2021, despite the merger of three Islamic banks in Indonesia, namely Bank Mandiri Syariah, BNI Syariah, and BRI Syariah to become Bank Syariah Indonesia (BSI). It is hoped that it is not only because of following the qanun, but the public awareness that Islamic banks are better than conventional ones.

\section{CONCLUSIONS}

Based on the results of research and discussion, it can be concluded that nationally the financial literacy of the Indonesian people is still relatively low, but for the Aceh region itself it is higher than the level of public understanding of sharia finance in Aceh is above the average public understanding of sharia banking nationally.

The interest of the Acehnese people in transacting in Islamic banking is currently increasing, as can be seen from the increasing graph in terms of assets, financing, and third party funds, especially in 2021. 
Financial Literature And Interest Of Aceh People In Transactions In Sharia Financial Institutions Post Implementation Of Qanun Sharia Financial Institutions In Aceh

\section{REFERENCE}

Abdullah, Mohamad Azmi \& Alex Anderson. (2015). Islamic Financial Literacy among Bankers in Kuala Lumpur. Journal of Emerging Economies and Islamic Research, 1-16

Al-Tamimi, H.A. Hassan \& Al Anood Bin Kalli. (2009). Financial Literacy and

Investment Decisions of UAE Investors. Journal of Risk Finance, 500-516

Andrew, Vincentius \& Nanik, L. (2014). Hubungan Faktor Demografi dan Pengetahuan Keuangan dengan Perilaku Keuangan Karyawan Swasta di Surabaya. Finesta, 35-39

Antara, P. M., Musa, R., \& Hassan, F. (2016). Bridging Islamic Financial Literacy and Halal Literacy: The Way Forward in Halal Ecosystem. Procedia Economics and Finance, 37, 196-202.

ANZ Survey. (2011). Adult Financial Literacy In Australia. The social research centre

Arrondel, Luc., Majdi Debbich \& Frédérique Savignac. (2013). Financial Literacy and Financial Planning in France. Advancing Education in Quantitative Literacy

The Association of Chartered Certified Accountants (2014)

Lusardi, A., \& Mitchell, O. S. (2011). Financial Literacy Around The World: An

Overview. Journal of Pension Economics and Finance,10 (4): 497-508

Mahdzan, Nurul Shahnaz \& Saleh Tabiani. (2013). The Impact Of Financial Literacy On Individual Saving: An Exploratory Study In The Malaysian Context. Transformations in Business \& Economics, Vol.12, 41-55

Irawan. (2009). Analisis Faktor-Faktor Yang Mempengaruhi Minat Nasabah Dalam Memutuskan Menabung di Bank Syariah Mandiri Cabang Malang. Malang. Skripsi S-1. Universitas Islam Negri Malang.

Sekaran. 2007. Metodologi Penelitian untuk Bisnis. Edisi 2. Penerbit Salemba Empat.

Soemitro, Andri. (2009). Bank \& Lembaga Keuangan Syariah cetakan kedua. Jakarta: Prenada Media.

Sudarsono, Heri. (2003). Bank \& Lembaga Keuangan Syariah. Yogyakarta. 